\title{
THE ORTHODOXY OF THE 'Q' SAYINGS OF JESUS
}

\author{
Edward P. Meadors
}

\begin{abstract}
Summary
Many recent studies of ' $Q$ ' presuppose that it reflects a 'variant' or 'second sphere' of primitive Christianity which was not influenced by the preaching of the cross. This assumption is misleading, however, because Jesus' sayings, as represented in $Q$, are fully compatible in content with their synoptic contexts. The lack of allusions in $Q$ to Jesus' death and resurrection reflect the historical span of time in the early to middle stages of his ministry when the sayings were originally voiced. Neither Matthew, Mark, nor Luke contain full-blown early church doctrines of the atonement, therefore, $Q$ does not contradict its synoptic environment.
\end{abstract}

\section{Introduction}

Walter Bauer's 1934 book Rechtgläubigkeit und Ketzerei im ältesten Christentum 1 defines orthodoxy or the 'ecclesiastical position' along the following four points:

1) Jesus revealed the pure doctrine to his apostles, partly before his death, and partly in the forty days before his ascension.

2) After Jesus' final departure, the apostles apportioned the world among themselves, and each took the unadulterated gospel to the land which was allotted him.

3) After the death of the disciples the gospel continued to spread but dissension sprang up within Christianity and heresy developed.

4) Right belief defeated false belief and orthodoxy was maintained within the church. ${ }^{2}$

Bauer's thesis is that this deeply rooted understanding of Christian origins may not be historically accurate. Instead, he speculates that at the very beginning Christianity may have been characterized by a plurality of beliefs, and some beliefs which the Church eventually castigated as heretical may originally have been, in some areas, the only forms of

${ }^{1}$ W. Bauer, ET Orthodoxy and Heresy in Earliest Christianity (London, SCM 1972).

Idem., xxxiii-xxxiv. 
Christianity. Thus, beliefs we now classify as orthodox and heretical emerged side by side-each as valid a form of Christianity as the other.

One specific body of gospel material which some New Testament scholars have identified as 'unorthodox' is the sayings source $Q$. The first to suggest the variant quality of $Q$ was H.E. Tödt who claimed that Q's distinctiveness rested in its peculiar selection of Son of Man sayings. Because $Q$ does not contain 'suffering' Son of Man sayings, Tödt identified $Q$ as an independent Christological tradition which strictly associated Jesus with the future exalted Son of Man. ${ }^{3}$ Later J.M. Robinson and H. Köester, ${ }^{4}$ like Tödt, detected a variant picture of Jesus within Q. Robinson and Köester, however, did not confine Q's Christology to the Son of Man tradition, but instead they addressed $Q$ as a body of wisdom sayings which fit in the midst of a wisdom tradition which stretched from ancient Jewish literature through the New Testament and on into later gnostic writings. In this scheme Jesus emerges as an 'envoy of wisdom', a figure radically different from Mark's suffering Son of Man who came 'to give his life a ransom for many', (10:45). Robinson and Köester went still further to say that $Q$ not only represents a variant tradition, but it represents 'the most original Gattung of the Jesus tradition.'

Similar to Robinson, Köester, and Tödt, S. Schulz, in the Foreword of his massive commentary on $Q$, set as his guiding presupposition the notion that plurality of belief characterized Christianity at its inception. 6 Schulz clearly

\footnotetext{
${ }^{3}$ H.E. Tödt, The Son of Man in the Synoptic Tradition (Philadelphia, Westminster 1965) 235. Tödt's thesis, however, has not won wide support. See I.H. Marshall, 'The Synoptic Son of Man Sayings in Recent Debate', NTS 12 (1965/66) 327-51; O.J.F. Seitz, 'The Rejection of the Son of Man; Mark Compared with Q', Studia Evangelica (1982) 451465; Christopher Tuckett, 'The Present Son of Man' JSNT 14 (1982) 5882.
}

${ }^{4} \mathrm{~J} . \mathrm{M}$. Robinson and H. Köester (eds.), Trajectories through Early Christianity (Philadelphia, Fortress Press 1971).

${ }^{5}$ Helmut Köester, 'Gnomai Diaphoroi: The Origin and Nature of Diversification in the History of Early Christianity', in Robinson and Köester, op.cit., 135.

${ }^{6} \mathrm{~S}$. Schulz, Q Die Spruchquelle der Evangelisten (Zürich, Theologischer Verlag 1972) 5: 'Die älteste Urchristentum war traditionsgeschichtlich und kerygmatisch keine Einheit'. . .'Das Urchristentum. . .war von 
advances W. Bauer's theory of Christian origins. The $Q$ material represents the preaching of one specific isolated early Christian community (or series of communities) whose understanding of Jesus' significance is uniquely its own.

While the work of Robinson, Köester, and Tödt successfully influenced many scholars that $Q$ contained an 'unorthodox' Christological tradition which was entirely distinct from the narrative-kerygma of Mark's gospel, more recent scholarship has failed to agree on the precise identification of $Q^{\prime}$ s Christology: whether its distinction lies in its identification of Jesus as an emissary of Wisdom, ${ }^{7}$ as Wisdom herself, 8 as a prophet like the prophets of Old Testament tradition, 9 as a figure who combines wisdom and prophetic tendencies, 10 or as an exalted figure whose earthly existence originally had no Christological significance at all.11 There is agreement, however, among a growing number of scholars that Q's portrait of Jesus is radically different from that of Mark, and that the evidence for $Q$ 's variance springs from its silence on the meaning of Jesus' death and resurrection and its omission of suffering Son of Man sayings. Hence J. Kloppenborg has recently written:

... it has become quite usual to speak of 'the community of $Q$ ' as a definable and autonomous group within primitive Christianity and to assume that the $Q$ document reflects in some important way the theology of a 'second sphere' of primitive Christianity uninfluenced by the kerygmatic assertion of the saving significance of Jesus' death and resurrection. Implicit in this is the suggestion that $Q$

Anfang an eine komplexe Größe mit unterschiedlichem Traditionsmaterial und unterschiedlichen kerygmatischen Entwürfen, die auf verschiedene selbständige Gemeinden schließen lassen'.

${ }^{7}$ M. Jack Suggs, Wisdom, Christology, and Law in Matthew's Gospel (Cambridge, Harvard University Press 1970); J.D.G. Dunn, Christology in the Making (Philadelphia, Westminster 1980) 198ff.; C.E. Carlston, 'On " $\mathrm{Q}$ " and the Cross', in Scripture, Tradition, and Interpretation, $\mathrm{W}$. Gasque and William LaSor (eds.), (Grand Rapids, Eerdmans 1978) 30. 8Felix Christ, Jesus Sophia (Zürich, Zwingli-Verlag 1970) 69, 73, 93.

${ }^{9}$ Migaku Sato, $Q$ und Prophetie: Studien zur Gattungs- und Traditionsgeschichte der Quelle Q (Tübingen, J.C.B. Mohr 1984) 69-95. 10R.A. Edwards, A Theology of $Q$ (Philadelphia, Fortress 1976) 150. 11Schulz, op.cit., 482: M. Eugene Boring, Sayings of the Risen Jesus (Cambridge, CUP 1982) 182: What Jesus of Nazareth had said became dissolved in what the post-Easter Jesus said through his prophets'. 
represents the main and guiding theological statement of a particular community or group of communities. 12

Central to this concept of $Q$ is the hypothesis that where $Q$ is silent on the passion kerygma it must preach something else. $Q$, therefore, it is said not only has a unique Christology, but also a variant soteriology. Jack D. Kingsbury, for instance, argues that in $Q$ salvation is tied not to Jesus' death and resurrection, but to Jesus' return as the future Son of Man. ${ }^{13}$ Or from a different perspective, C.E. Carlston claims salvation (within $Q$ ) is seen as the literal carrying out of Jesus' teachings-Jesus' teachings, therefore, have become an end in themselves.14 The cumulative result of these studies is the conviction that $\mathrm{Q}$ can no longer be classified as mere teaching, but must be considered as a self-contained 'unorthodox' kerygma which exists within Matthew and Luke right alongside the orthodox kerygma of Mark.15 Mark and $Q$, therefore, are understood to be Christologically and soteriologically incompatible-the products of two different Christological traditions.

At this point it is worth noting that the issue before us-that of competing or variant Christologies or kerygmas is not a phenomenon exclusive to radical scholars. The idea has won moderate supporters including the before-mentioned Jack Dean Kingsbury who writes:

Because the 'passion kerygma' is so central to early Christian proclamation, scholars have questioned whether there could have arisen within nascent Christianity any theological document of

12J.S. Kloppenborg, "Easter Faith" and the Sayings Gospel Q', Semeia 49 (1990) 71.

${ }^{13}$ Jack D. Kingsbury, Jesus Christ in Matthew, Mark, and Luke (Philadelphia, Fortress 1981) 24-25: 'Instead, within the context of the history of salvation the members of the $Q$ community look to the final judgement as the locus of salvation ( $L k .12: 8,9,40 ; 17: 24,30$ )'.

${ }^{14} \mathrm{C}$.E. Carlston, Gasque and LaSor (eds.), 29-30: ' $Q$ reflects a tendency, known elsewhere in early Christian literature but particularly clear in Gnosticism, to concentrate not on the death of Jesus but on his teaching. . .' Jesus' teaching, however, also plays an important role in Mark's portrait of Jesus' ministry. See R.T. France's excellent article, 'Mark and the Teaching of Jesus', in Gospel Perspectives I (Sheffield, JSOT Press 1980) 101-36.

${ }^{15} \mathrm{~J} . S$. Kloppenborg, ' $Q$ as Kerygma', in The Formation of $Q$ (Philadelphia, Fortress Press 1987) 22-7. 
importance that did not, as Mark, highlight the death and resurrection of Jesus. It may be that in $Q$ one has just such a document, for in place of proclaiming the cross, $\mathrm{Q}$ lays stress on the imminent return of Jesus Son of Man for judgment. ${ }^{16}$

\section{The Thesis Examined}

The purpose of this article is to respond to this perception of the Christological and soteriological disparity between Mark and $Q$, and to test the hypothesis that Mark and $Q$ represent inconsistent kerygmas-if, indeed, we are right in using such terminology at all. We believe there are good textual grounds for claiming exactly the opposite of what the above scholars argue-that Mark and $Q$ have compatible (not parallel, but compatible) Christological and soteriological emphases.

$Q$ does not contain a passion narrative. In sharp contrast, New Testament scholars of all persuasions agree that Mark focuses upon the cross as the decisive event which reveals Mark's answer to Jesus' identity and his significance. $\mathrm{Q}$, therefore, is silent on the very theme, Jesus' passion, which climaxes the Christology of Mark. Our question, as a result, is this: Is Q's silence valid evidence of a variant early Christian kerygma?

But before we move to the heart of our essay it is necessary to expose the hypothetical nature of the scholarly enterprise under review. The presuppositions crucial to the above perceptions of Mark and $\mathrm{Q}$ abound. The so-called ' $\mathrm{Q}$ Community' precipitates entirely from twentieth century critical methodology as opposed to hard historical or archaeological evidence. Despite its acceptance by the major critical commentaries of the Synoptic Gospels, $17 \mathrm{Q}$ itself remains a hypothesis. Redactional layers, historical phases,

16Kingsbury, op. cit., 1.

17W.D. Davies and Dale Allison, Matthew (Edinburgh, T. \& T. Clark 1988) 1991; J. Gnilka, Das Matthäusevangelium (Freiburg, Herder 1986, 1988); U. Luz, Das Evangelium nach Matthäus, (Mt. 1-7) (Zürich, Benziger 1985); H. Schürmann, Das Lukasevangelium (Freiburg, Herder 1969); I.H. Marshall, Luke (Grand Rapids, Eerdmans 1978); J. Fitzmyer, Luke (New York, Doubleday 1981, 1985); F. Bovon, Das Evangelium nach Lukas, (Lk. 1,1-9,50) (Zürich, Benziger 1989); R. Pesch, Das Markusevangelium (Freiburg, Herder 1976); J. Gnilka, Das Evangelium nach Markus (Zürich, Benziger 1978, 1979); R.A. Guelich, Mark (Dallas, Word 1989). 
and levels of Christological development within $Q$ represent hypotheses twice removed. While the above scholars tend to categorize Mark as narrative and $Q$ as a sayings collection, we observe that $Q$ contains some narrative material and Mark incorporates isolated sayings and sayings chains. The two are not formally alienated from one another.

\section{III. $Q$ and the Synoptic Gospels}

In order to answer this question, first we will evaluate the passion narratives' impact on gospel material outside $Q$. Is $Q^{\prime}$ s apparent silence a stark contrast to its synoptic environment?

In answer to this question, we first observe that despite the fact that the synoptic Gospels contain passion narratives, 'the theology of the cross' does not surface as the consistent explicit emphasis of Matthew, Mark, or Luke. Matthew and Mark each contain only two direct references to the atoning value of Jesus' death (Mk. 10:45;14:22-24; Mt. 20:28;26:28). 18 Luke, meanwhile, speaks the least on Jesus' death as Luke 22:27 omits the ransom clause of Mark 10:45 leaving only Luke 22:19f. which associates Jesus' death with the new covenant of Jeremiah 31:31. Outside this handful of references, the atoning value of Jesus' death is implied primarily in the association of Jesus with the Suffering Servant of Isaiah. With Luke 22:37 being the only direct quotation of Isaiah 53:12 in the synoptics, the degree, however, to which the Gospel writers compare Jesus with the Suffering Servant is a continuing subject of controversy. In our perspective Morna Hooker,19 C.K. Barrett, ${ }^{20}$ C.F.D. Moule ${ }^{21}$ and others have under-estimated

${ }^{18}$ These references, however, provide strong evidence that the concept of redemption can be traced back to the teaching of Jesus himself. See France, op.cit., 32-39; I.H. Marshall, 'The Development of the Concept of Redemption in the New Testament', Reconciliation and Hope: Presented to L.L. Morris (ed. R.J. Banks) (Exeter, Paternoster 1975) 15369.

${ }^{19}$ M.D. Hooker, Jesus and the Servant (London, SPCK 1959).

${ }^{20}$ C.K. Barrett, 'The Background of Mark 10:45', in New Testament Essays: Studies in memory of T.W. Manson, (ed. A.J.B. Higgins) (Manchester University Press) 40-53.

${ }^{21}$ C.F.D. Moule, 'From Defendant to Judge-and Deliverer: an Enquiry into the Use and Limitations of the Theme of Vindication in the New Testament', Studiorum Novi Testamenti Societas Bulletin (1959) 1-18. 
the importance of the allusions to the Suffering Servant in the synoptic gospels, 22 but we do agree that the servant allusions are implied and can hardly be identified as clear statements of the early church kerygma.23

The purpose of making these general observations is to show that Q's failure explicitly to interpret the cross is quite characteristic of the synoptic gospels as a whole. When Matthew, Mark, and Luke rarely present direct references to the atoning benefits of Jesus' death, should we find it remarkable that $Q$ is silent on the same issue? On the contrary, it would seem abnormal if $Q$ did frequently refer to the cross in qualifying terms. ${ }^{24}$ The refusal of Matthew, Mark, and Luke to place on Jesus' lips sayings which explicate the salvific benefits of Jesus' death suggests the synoptic writers' allegiance to the historical material at their disposal.

\section{IV. ' $Q$ and Deuteronomistic Theology'}

But if Q's silence does not raise our suspicions, what can we say to the positive evidence supporting an 'unorthodox' interpretation of Jesus' death within Q? Charles Carlston, ${ }^{25}$

22The one formal quotation (Lk. 22:37) and the two allusions (Mk. $10: 45 ; 14: 24)$ to Is. $53: 12$ are few and complex in their linguistic relation to the LXX and MT. However, the linguistic parallels do exist and provide a better solution, in our opinion, to the background of these synoptic sayings than does the hypothesis that Mk. 10:45 alludes to Daniel 7 where the Son of Man is an exalted worshipped figure. On the linguistic debate see, R.T. France, 'Servant of the Lord in the Teaching of Jesus', TynB 19 (1968) 26-52.

${ }^{23}$ We concur with Chrys Caragounis: 'Thus, though affinities between Mk. 10:45 and Isa. 53 are recognized, these are not strong enough to warrant the theory that the logion is the creation of the Palestinian Church on the basis of Isa. 53', The Son of Man: Vision and Interpretation (Tübingen, J.C.B. Mohr 1986) 191.

${ }^{24}$ The same argument could be put forward in respect to the Pauline letters. See D. Allison, 'The Pauline Epistles and the Synoptic Gospels', NTS 28 (1982) 16.

${ }^{25}$ Carlston, in Gasque and LaSor, op. cit., 30. 
Paul Hoffmann (with modifications), ${ }^{26}$ Arland D. Jacobson, 27 John Kloppenborg,28 James Robinson,29 Siegfried Schulz,30 Richard A. Edwards, ${ }^{31}$ Dieter Lührmann ${ }^{32}$ and Dieter Zeller ${ }^{33}$ agree in claiming that $Q$ interprets Jesus' death against the background of the 'deuteronomistic tradition' as outlined by O.H. Steck. ${ }^{34}$ According to Steck the 'deuteronomistic tradition' follows a four phase pattern: (1) Israel's history is a story of rebellion; (2) God sent his prophets to call the disobedient people to repent in order to avoid judgment; (3) Israel rejected, persecuted, and killed the prophets sent to her; (4) hence Israel faces destruction as it did in 722 and 586 B.C. Fitting into this pattern, Jesus' death within $Q$ has the same significance as the Old Testament prophets who died before him-and no more. Kingsbury again represents this view when he writes:

A remarkable feature of $Q$ is that no direct mention is made of the cross of Jesus. The one time the word 'cross' occurs is in a saying of Jesus which speaks of the cost of discipleship: Whoever does not bear his own cross and come after me, cannot be my disciple' (Lk. 14:27). What can be inferred about Jesus from this passage, however, is clear: the community of $Q$ conceives of his death in terms of martyrdom. In its eyes, Jesus has suffered the fate of John

26P. Hoffmann, 'Die Deutung des Todes Jesu unter dem Einfluß der Propheten-Tradition und des Menschensohn-Bekenntnisses', in Studien zur Theologie der Logienquelle (Münster, Verlag Aschendorff 1971) 187-90; pace O.H. Steck, Israel und das gewaltsame Geschick der Propheten (Neukirchen-Vluyn, Neukirchener Verlag 1967) 161-2.

27Arland D. Jacobson, 'The Literary Unity of Q', JBL 101 (1982) 365-89.

${ }^{28}$ Kloppenborg, The Formation of $Q, 27 ;$ " 'Easter Faith and the Sayings Gospel Q', 92.

${ }^{29}$ Robinson, 'The Gospels as Narrative', in The Bible and the Narrative Tradition, (ed. Frank McConnell), (New York, OUP 1986) 107.

${ }^{30}$ Schulz, op. cit., 483.

${ }^{31}$ Edwards, op. cit., 149,150 .

32D. Lührmann, 'The Gospel of Mark and the Sayings Collection $Q^{\prime}, J B L$ 108 (1989) 64.

${ }^{33} \mathrm{D}$. Zeller, Kommentar zur Logienquelle (Stuttgart, Katholisches Bibelwerk 1984) 96,97 .

${ }^{34}$ O.H. Steck, op. cit., 266-268. The OT background for the deuteronomistic pattern unfolds as follows: (1) Israel's disobedience (Ne. 9:26-30; 2 Ch. 30:7,8; $2 \mathrm{Ki} .17: 11-12) ;(2)$ Warning to repent (Ne. 9:26,30; 2 Ki. 17:13); (3) Israel's refusal to repent (Ne. 9:26,29-30; 2 Kgs 17:14-17,19); (4) God's Judgment (Ne. 9:30; 2 Ki. 17:18,20), 62-4, 122-4. 
the Baptist and all the prophets (Lk. 11:47-51;13:34). In stark contrast to Mark's Gospel, therefore, the cross is not the locus of salvation in Q. ${ }^{35}$

In reaching this conclusion, Kingsbury makes a methodological jump characteristic of the perspective we are criticizing. After

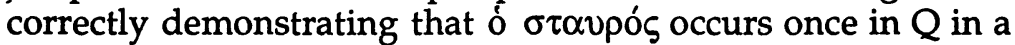
saying dealing with discipleship, Kingsbury then illogically applies the pertinence of the Luke 14:27 parallel exclusively to the hypothetical $Q$ community who apparently viewed Jesus as a typical martyr. But Luke 14:25-27//Matthew 10:37-38, while possibly alluding to Jesus' eventual death does not qualify the meaning of Jesus' execution any more than does its doublet in Mark 8:34; (Lk. 9:23; Mt. 16:24). The burden of each version is discipleship. And suffering, even martyrdom, is consonant with discipleship not only in $Q$ and Mark, but also in Acts, in the Pauline corpus and indeed throughout the New Testament.

Nevertheless the 'deuteronomistic tradition' is said to pervade the $Q$ material ${ }^{36}$ and three $Q$ passages in particular seem to fit Jesus' death into the deuteronomistic mould. ${ }^{37}$

\section{Luke 11:47-51//Matthew 23:29-31,34-36}

In the first $Q$ passage which possibly foreshadows Jesus' death, Jesus warns his opposition that they are guilty of the same crimes which their ancestors committed when they murdered and persecuted the prophets and apostles (Mt. has prophets, wise men, and scribes). Because of their part in these crimes, this generation will be punished-justice is required ( $\varepsilon \kappa \zeta \eta \tau \dot{\varepsilon} \omega)$ of them. The sense is that Jesus' opponents are completing the evil task which their forefathers began; therefore, they are responsible for all the innocent blood which has been shed from Abel to Zechariah.

Our present interest lies in the latter part of this passage, (Lk. 11:49-51//Mt. 23:34-36), for it is in these verses that recent scholars have found allusions to Jesus' martyrdom within Q. At the outset, however, it should be noted that Jesus'

35Kingsbury, op. cit., 24-5.

36Jacobson, op. cit., (384) isolates Q passages which fit each of Steck's phases.

${ }^{37}$ Lührmann, following Steck cites also Lk. 6:23//Mt. 5:12 as identifying Jesus' death as the typical fate of the prophets: op. cit., 64. Lührmann's reasoning, however, is highly speculative as Davies and Allison warn: cf. op. cit., 463 n. 55. 
death is nowhere mentioned. Scholars who discover here a statement on Jesus' death must maintain that the $Q$ community included Jesus among those who were killed between the time of Abel and that of Zechariah. As a result, Zechariah can neither be identified as Zechariah, the son of Jehoiada, who was stoned in the court of the temple (2 Ch. 24:20-22) or Zechariah the writing prophet (Zc. 1:1) as both of these figures died well before the time of Jesus. To maintain that this passage alludes to Jesus' death, one must identify Zechariah as Zechariah the son of Bareis (cf. the Mt. account which reads Zechariah the son of Barachias) who was slain by zealots in the temple in AD 67.38 This reading, however, is very unlikely as it depends on the hypothesis that Luke omitted viov Bapaxiov from the original $Q$ reading while Matthew retained the original form. ${ }^{39}$ In a parallel which is generally characterized by Matthean redaction 40 rather than Lukan omission, 41 it is more likely that Luke's Zox opiov is the original form and refers to Zechariah the son of Jehoida. In this case $Q$ (Lk. 11:49-51//Mt. 23:34-36) does not present Jesus' death as the fate common to prophets. The clear comparison, rather, is between Jesus' opponents and their ancestors.

Images of martyrdom and the basic contours of the 'deuteronomistic tradition', therefore, do colour this $Q$ passage, 42 but it is the prophets of old, the righteous, who surface as the martyr figures. While Luke 11:49-51//Matthew 23:34-36 may implicitly refer to Jesus' death it does not qualify the meaning of his crucifixion. To claim that it is a statement by a community which attached no significance to Jesus' death is to argue what the text does not support.

38Jos. Bel. 4:334-44. This is the view of O.H. Steck, op. cit., 37-40.

${ }^{39}$ Most ' $Q$ scholars' perceive it improbable that viov $B \alpha \rho \alpha \chi i o v$ originally stood in Q: Schulz, Q, op.cit., 338; Ernst Haenchen, Matthäus 23' ZTK 48 (1951) 45; D. Lührmann, Redaktion der Logienquelle, 47; P. Hoffmann, op. cit., 165.

40D.E. Garland, The Intention of Matthew 23 (Leiden, Brill 1979) 171-87.

${ }^{41}$ Marshall, Luke, 506.

$42 \mathrm{On}$ the conception of martyrdom behind Lk. 11:49-51//Mt. 23:34-6, see Ethelbert Stauffer:' "iv $\alpha^{\prime}$, TDNT III, 328 n. 46. 


\section{Luke 13:34-35//Matthew 23:37-39}

The second $Q$ passage which is said to refer to Jesus' death originally may have existed side by side with Luke 11:4751//Matthew 23: 29-36 in which case Matthew's order would represent the original arrangement of $Q$. The Lukan vocabulary, however, probably adheres closer to the $Q$ prototype. 43 We cite the 'Lament over Jerusalem' with the primary question in mind: does this saying clearly qualify Jesus' death as the death of a martyr and no more? In Luke Jesus' death is definitely in view as a result of its proximity to 13:33: 'because it is not possible for a prophet to die outside of Jerusalem'. Luke 13:33 provides evidence that Luke at least did not perceive discontinuity between Jesus' death as a prophet and his death as the suffering Messiah. Can we be sure that what was true for Luke was not also true for the transmitters of the $Q$ material?

Like the preceding passage, the 'Lament over Jerusalem' fails to present an explicit statement which interprets Jesus' death or even identifies it. Again the allusion to Jesus' fate is revealed through the association of Jesus with the prophets and 'those sent' to Jerusalem. While the comparison between Jesus and the prophets is understood, it is not clear that Luke 13:34//Matthew 23:37 understands Jesus to be on par ontologically with the prophets killed and messengers stoned in Jerusalem. 44 More likely the passage represents Jesus' free use of wisdom terminology 45 in administering judgment to the Jerusalem authorities who share the responsibility for killing the prophets and messengers of God. As Jerusalem refused to repent and to seek God's protection at the preaching of ancient prophets, so she has now refused to repent at the preaching of Jesus. As the prophets' murderers will be punished, so those who reject Jesus will face eschatological judgment (cf. Lk. 11:47//Mt. 23:29).

${ }^{43} \mathrm{Cf}$. Steck, op. cit., 48-50.

${ }^{44}$ Eduard Lohse notes the unlikelihood of such a reading, 'Mt. 23:37 par. Lk. 13:34 speaks of stoning and putting to death, not crucifying; hence it cannot be called vaticinium ex eventu', in 'Sayings of Jesus about Jerusalem', TDNT VII, 329 n. 236. Garland (op. cit., 23, 177) attributes Matthew's $\sigma \tau \alpha \cup \rho \omega ́ \sigma \varepsilon \tau \varepsilon$ to Matthean redaction.

45So Marshall, Luke, 574. 
When emphasis does turn to Jesus as speaker (Lk. 13:34b//Mt. 23:37b), the subject moves from Jerusalem's guilt in murdering God's messengers to Jerusalem's rejection of Jesus' personal offer of protection. In identifying himself as the figure on whom depends the Jews' unification and salvation, Jesus assumes authority which surpasses that of the Old Testament prophets. Thus Jerusalem's house is left desolate (Lk. 13:35//Mt. 23:38) because it has rejected Jesus' offer of salvation-not because it has murdered Jesus. In saying, 'How often I wanted to gather your children together the way a hen gathers her chicks under her wings', Jesus assumes exalted status as the figure intended to occasion the gathering of God's eschatological people into the Kingdom of God. In this regard, Jerusalem's rejection of Jesus paves the way for the synoptic passion narratives where Jesus describes his death as 'the blood of the covenant which is poured out for many' (Mk. 14:22-25).46 In the end Jesus' death accomplishes the feat originally intended by his call to repentance and his preaching of the Kingdom of God. Finally, You will not see me until you say "Blessed is he who comes in the name of the Lord"' (Lk. 13:35b//Mt. 23:39), appears to be a strange conclusion to a saying which alludes to Jesus' martyrdom. Temporally the saying points to the future rather than to the past, and focuses on Jesus' exaltation rather than his demise. Indeed, the saying may very well be an implicit identification of Jesus' messiahship. 47 In any case, 'Blessed is he who comes in the name of the Lord' is anomalous to descriptions of Old Testament prophets and John the Baptist.

\section{Luke 14:27//Matthew 10:38}

The final $Q$ passage which possibly alludes to Jesus' death is a statement which Matthew and Luke both use to describe the cost of discipleship. Jesus warns the audience, the twelve or more likely the crowd at large, that obedience to himself must

46So R. Schnackenburg, God's Rule and Kingdom (London, Nelson 1963) 250: 'After the failure of his preaching to the Jews, Jesus regards his Passion as a necessary precondition for the coming of the perfect kingdom'.

47 Marshall points out that Jesus spoke in similar terms of the future coming of the Son of Man: 'Here, however, the symbolism is messianic (perhaps as a result of assimilation of the two figures) and contains an implicit identification as the coming One, the Messiah', Luke, 577. 
be unconditional-even to the point of death. To refuse to suffer is to fail the test of discipleship.

The inclusion of $\tau$ òv $\sigma \tau \alpha u p o ̀ v$ in both the Matthean and Lukan versions presents historical difficulties for commentators and suggests to some scholars an after the fact allusion to Jesus' death. Again, however, it must be stressed that this passage, like the previous two we have discussed, is neither a description of Jesus' death, nor an interpretation of why Jesus died. It is the audience which is advised to take up the cross. ${ }^{48}$ If, therefore, the saying refers to Jesus' death at all, it does so faintly without a hint of the $Q$ community Tendenz.

Moreover, it is very unlikely that this saying reflects a unique perspective of the $Q$ community because it repeats teaching found in Luke (9:23,18:29f.), and is in fact a ' $Q$ doublet' to Marcan teaching (8:34). This problem is not removed with the claim that Mark used $Q$, as Mark 8:34 is equally primitive and also focuses on the theme of discipleship. An equally valid argument could be used to support Mark's originality. 49

Furthermore, the argument that Luke 14:27//Matthew 10:38 alludes to Jesus' martyrdom is not strengthened if the assumption is made that the saying is secondary. .00 For it is one thing to say that this logion alludes to Jesus' death on the cross, and it is another thing to argue that the saying (1) denies the orthodox interpretation of the cross, and (2) presents a separate tradition in which Jesus' crucifixion is categorized purely as typical martyrdom. Such appraisals are made entirely from silence. For if this saying advances a view of Jesus' death which is in some way incompatible with the Marcan passion narrative, it is hard to understand why the author or editor of Mark included 8:34 in his narrative. If his objective was to 'correct' a heretical Christology or

${ }^{48}$ 'It presents to the disciple the challenge of readiness for martyrdom', Fitzmyer, op. cit., I, 787.

${ }^{49}$ So Schürmann, 'Daß die Nachfolge bei Mk gleich einleitend als Ziel genannt ist, könnte durchaus auch ursprünglich sein', in op. cit., I, 542; cf.: R. Laufen, Die Doppelüberlieferungen der Logienquelle und des Markusevangeliums (Königstein/Ts.-Bonn, Peter Hanstein 1980) 308.

${ }^{50}$ On the saying's secondary origin see Fitzmyer, op. cit., 785. Fitzmyer, however, obviously is not arguing that the phrase refers to Jesus' death as the common fate of a martyr. A plausible case, however, can be made for authenticity: see V. Taylor, Mark (London, Macmillan 1966) 381. Taylor's reasoning on $\mathrm{Mk}$. 8:34 is valid also for the $Q$ version. 
soteriology, would not his task have been easier and more effective if he had simply left out the saying all together? We agree with Kingsbury that such corrective tendencies are not evident in Mark.51 It seems more reasonable that Mark's inclusion of 8:34 testifies to the saying's compatibility with Mark's understanding of discipleship and with the passion narrative which follows. It is not a valid hypothesis, therefore, to assume that Luke 14:27//Matthew 10:38 offers an unorthodox perspective of Jesus' death.

Together these passages reflect a historical perspective that the prophets and the righteous men of old died characteristically violent deaths. Because the image permeates the Old Testament, inter-testamental literature, and the New Testament outside $Q$ (Mk.12:1-9; 1 Thes. 2:14-16), we do not consider the theme's presence in $Q$ to be evidence of a variant kerygma. 52

But do the $Q$ passages mentioned contradict the early church's proclamation that Jesus died as an atoning sacrifice for the forgiveness of sins? Several general observations suggest that we approach this question with extreme caution. First, these passages do not in themselves directly speak of or interpret the meaning of Jesus' death and, therefore, cannot be said to deny or contradict the passion kerygma. We are dealing with an argument from silence. Second, because the sayings under question are very allusive and are only three in number out of a collection of roughly 230 verses, we must question the bold and perhaps radical claim that these verses earmark a variant early Christian response to Jesus' death. Third, it may be a pertinent question to ask whether or not the martyr image satisfies the Christological implications of the surrounding $Q$ material. For even if we speculate that Tödt is correct-that it was the $Q$ community which originally associated the exalted Son of Man with the earthly Jesus-even then, we are still left with the question of how or why the supposed community

${ }^{51} \mathrm{~J} . \mathrm{D}$. Kingsbury, The Christology of Mark's Gospel (Philadelphia, Fortress 1983) 33f.

52See the references to the deuteronomistic motif offered in Davies and Allison, op. cit., 465. See also H.J. Schoeps, Aus früchristlicher Zeit (Tübingen, 1950); H.A. Fischel, 'Martyr and Prophet', JQR 37 (1946-7) 265-80, 363-86; B.H. Amaru, 'The Killing of the Prophets: Unraveling a Midrash' HUCA 54 (1983) 153-80. 
came to make such an association. Is it conceivable that a body of Gospel literature which identifies Jesus as the Son of God in the temptation narratives, which anticipates Jesus as the future Son of Man, and which presents Jesus speaking to God as a son to a father ( $\mathrm{Lk}$. 10:22//Mt. 11:27), is consistent in the end when it reduces itself to categorize Jesus' death as the fate typical of all the prophets? Fourth, we are hesitant to accept the martyr image as peculiar to $Q$ owing to the motif's frequent appearance in the New Testament (see Mk. 6:4; 12:25; Jn. 4:44; Acts 7:51-2; Rom. 11:3; Heb. 11:32-38; Jas. 5:10-11; Rev. $11: 6-7 ; 16: 16 ; 18: 24)$ where suffering and martyrdom is consonant with Christian discipleship. 53 Just as these passages obviously do not suggest that the disciple's death has the same saving ramifications as did Jesus' death on the cross, so there are no grounds for the claim that the transmitters of $Q$ equated Jesus' death with that of his prophetic forebears. When martyr motifs exist within New Testament documents which address the redemptive significance of Jesus' death, we fail to see how its presence in $Q$ suggests Christological variance. And finally martyr terminology-if indeed alluded to-does not necessarily counteract the redemptive value of Jesus' death. There are Jewish texts in which the death of martyrs effectively delivers Israel from its sin and sin's consequences (Dn. 11:35, 2 Macc. 7:37-38, and 4 Macc. 17:22). 54 The martyr, therefore, does exist within Jewish literature as a figure which expresses redemptive ideas. 55

53See also: Mk. 4:17; 8:34; 10:30; Acts 5:40,41; 7:54-60; 11:19; 12:2-4; 13:50; 14:22; 16:22f; 17:6f; 21:13, 27-40; 23:12-22; 2 Cor. 1:5; 4:8-12; 1 Thes. 1:6; 3:3; 2 Thes. 1:4,5; 2 Tim. 3:12; Heb. 10:32-4; Rev. 1:9; 2:9,10.

54 See D. Hill, Greek Words and Hebrew Meanings, SNTSMS 5 (Cambridge, CUP 1967) 23-48; esp. 41-8. Hill claims that the language of 4 Macc. may have had a direct influence on Paul in passages where the cost of redemption is the death of Christ (Rom. 3:24; 6:16-23; 7:14; Gal. 3). See also: I.H. Marshall, 'The Development of the Concept of Redemption in the New Testament', in Reconciliation and Hope: Presented to L.L. Morris, (ed. R.J. Banks) (Exeter, Paternoster Press 1975) 153-69; Martin Hengel, The Atonement (London, SCM 1981) 60-5.

${ }^{55} \mathrm{~T}$. Baumeister, Die Anfänge der Theologie des Martyriums (Munster, 1980) $12 \mathrm{f}$., concedes that Israel did not have a 'theology of martyrdom' other than Is. 53:12 even in connection with the murder of the prophets. 
What is remarkable about Luke 11:47-51, 13:34-35, 14:27 and parallels, we believe, is the degree to which these verses anticipate and support the passion narratives. In the first two passages, which originally may have been united, Jesus appears in conflict with a representative group of Jewish authorities-the group which condemns Jesus to death in the passion narratives. When he sharply accuses the authorities as being responsible, with their fathers, for the murder of the prophets and righteous figures of Israel's history, Jesus administers a humiliating insult to the Jews-one which forecasts a future retaliation. In a similar light, Jesus' assumption of the authority to judge and to predict future judgment must have repulsed the Jews. And while it is true that the lament over Jerusalem presents Jesus bemoaning the plight of the prophets, the passage accentuates more strongly Jesus' grief that his people have rejected his own offering of protection. In this passage Jesus identifies himself as the final chance for Israel. He says in effect: because you have rejected me 'your house is left to you desolate.' The rejection of Jesus, therefore, has unprecedented consequences. Finally, the closing phrase: 'you shall not see me until the time comes when you say, "Blessed is he who comes in the name of the Lord"" (Ps. 118:26), clearly anticipates the triumphal entry (Lk. 19:38; Mt. 21:9) which quote the same Old Testament passage. In summary, it is plausible that orthodox early Christians showed interest in these passages and, indeed, interpreted them in the light of the passion narrative. Images of rejection, the cross, and Jerusalem have irrepressible connotations, and the reference to Psalm 118:26 identifies Jesus as a figure of no common merit.

Furthermore, the interpretation of Jesus within the pattern of 'deuteronomistic tradition' cannot be isolated to the Tendenz of the $Q$ community because, as J. Blank has shown, 56 it is Mark and not $\mathrm{Q}$ which provides the clearest portrait of

56J. Blank, 'Die Sendung des Sohnes. Zur christologischen Bedeutung des Gleichnisses von den bösen Winzern Mk. 12,1-12', in Neues Testament und Kirche, (ed. J. Gnilka) (Freiburg, Herder 1974) 11-41. On the parallels between Mk. 12:1-12 and Lk. 11:49-51 par.; Lk. 13:34-5 par, Blank writes (24): "Die beiden Q-Texte spiegeln genau dieselben Anschauungen wider, wie der Mk-Text 12,1-12. Die traditionsgeschichtlichen Denkmodelle sind genau die gleichen". 
Jesus as the consummation of Israel's rejection of the prophets. While Mark 6:4 affirms Mark's identification of Jesus as a prophet, the parable of the vineyard and the tenants gives prominence to Jesus' implied death as the climax to the 'deuteronomistic' pattern.

From this evidence we may conclude that the 'deuteronomistic tradition' is no more characteristic of $Q$ than Mark. In each the prophetic pattern of the rejection of the prophets culminates in Jesus himself.

Thus far, then, the theory of a variant or 'heretical' kerygma in $Q$ lacks supporting evidence. First, the argument from silence fails to startle us as a result of similar silence within Matthew, Mark, and Luke. Second the positive evidence of a contrary interpretation of Jesus' death falters upon the allusive character of the few $Q$ passages which are said to present Jesus as a common martyr figure-a figure which itself has complex connotations and which does not necessarily challenge 'orthodox kerygma'. And finally the 'deuteronomistic tradition' is a paradigm which $Q$ shares with Mark.

\section{Quotations and Allusions to the Old Testament within Q}

A final positive argument we raise to support the compatibility of Mark and $Q$ stems from the quotations and allusions to the Old Testament within $Q$. Athanasius Polag lists 23 quotations from the LXX within Q: nine from Isaiah; five from the Psalms; three from Deuteronomy; two from Jeremiah; and one each from Genesis, Exodus, Micah and Malachi.57 The UBS (3) index of quotations and allusions (pp. 897-911) confirms six of Polag's references as quotations, and identifies 37 additional allusions and verbal parallels to the Old Testament within $Q$. The margins of Nestle-Aland (26) expand this count further for a total of 85 for the combined existence of Old Testament quotations, allusions, and verbal parallels.

Our purpose in analyzing the Old Testament quotations and allusions is to seek to find any evidence that there exists a conceptual pattern in the Old Testament references which might betray the Christological or kerygmatic

${ }^{57}$ A. Polag, Fragmenta $Q$ (Neukirchen-Vluyn, Neukirchener Verlag 1979) $100-2$. 
bias of the supposed $Q$ community. While one searches in vain for even the slightest allusions to ancient Egyptian and Near Eastern sayings collections, Cynic literature, pre-Byzantine gnomologia, and later chriae collections, 58 a bird's eye view of Aland's references reveals that $Q$ may allude to as many as 19 different Old Testament books ranging from Genesis to Malachi and possibly to three inter-testamental writings. The conceptual background of the $Q$ material, then, is entirely Jewish. Further, $Q$ does not interpret Jesus in the light of a tradition isolated in one Old Testament book or even in a set of books such as the Penteteuch, the Prophets, or the Wisdom books proper. Hence, if $Q$ contains a variant tradition, and if that tradition draws from the Old Testament, which it must considering its quotations and allusions, then that tradition must interpret Jesus against a broad Old Testament background. Thus, prevalent Old Testament themes such as prophecy and wisdom are said to represent the variant conceptual background of $Q$.

But after going through the allusions and quotations individually, and then considering them as a whole, we are left with no sense of the unusual. Twelve categories represent the use of the Old Testament in Q:

1) General allusions to Old Testament historical figures and locations. 59

2) Strictly verbal allusions. 60

3) Allusions which cite Old Testament backgrounds for New Testament customs and orthopraxy. 61

4) Allusions to Old Testament pictorial images.62

${ }^{58}$ Contra Kloppenborg whose strict form critical methodology produces amazing parallels between $Q$ and other ancient sayings despite the impossibility of tracing the linguistic or conceptual pedigree of a single saying of Jesus to such a background. See 'Appendix 1', The Formation of $Q, 329-41$.

${ }^{59}$ E.g.: (1) Lk. 9:61,62//dif. Mt.: 1 Ki. 19:20; Ge. 19:17; (2) Lk. 10:13-15//Mt. 11:21-3: Jon. 3:5; Dn. 9:3; Esth. 4:3.

60E.g.: (1) Lk. 12:6,7//Mt. 10:29-31: 1 Sa. 14:45; 2 Sa. 14:11; (2) Lk. 12:53// Mt. 10:34-6: Mic. 7:6.

61E.g.: Lk. 14:20 : Dt. 24:5.

62E.g.: (1) Lk. 7:24//Mt. 11:7-9: 1 Ki. 14:15; (2) Lk. 13:19//Mt. 13:32: Dn. 4:9,18; Ez. 17:23; 31:6; Ps. 103:12 (LXX). 
5) Direct Quotations of the Old Testament which Jesus adopts in order to rebuke the temptations of Satan.63

6) Allusions which cite Old Testament terminology in reference to God.64

7) Teachings of Jesus which reflect Old Testament precursors. 65

8) Allusions in which Jesus assumes the role played by God in the Old Testament.66

9) Old Testament quotations which Jesus claims to fulfill in his ministry. 67

10) Allusions to the rejection of the prophets and righteous figures of Israel.68

11) Old Testament allusions which John the Baptist fulfills. 69

12) Eschatological expectations which parallel expectations of Old Testament passages. ${ }^{70}$

Drawn from a variety of Old Testament sources, the quotations and allusions serve specific purposes in the sayings in which they exist. An overarching framework, however, which might be constructed to present a variant portrait of Jesus is not apparent. For even $M$. Sato who perceives $Q$ to be analogous to Old Testament prophet books succumbs to the fact that in $Q$ Jesus is a figure of exceptional authority. ${ }^{71}$

63E.g.: Lk. 4:1-13//Mt. 4:1-11: Dt. 8:3; 6:13,16; 10:20.

64E.g.: (1) Lk. 11:20//Mt. 12:28: Ex. 8:19; (2) Lk. 12:5//Mt. 10:28: Ps. 119:120; (3) Lk. 15:3-7//Mt. 18:12-14: Ez. 34:11.

65E.g.: (1) Lk. 6:33//5:45-7: Lv. 25:35; (2) Lk. 12:22,31//Mt. 6:25-33: Is. 41:14; (3) Lk. 17:3,4//Mt. 18:21,22: Lv. 19:17; Ps. 119:164; (4) Lk. 10:47//Mt. 10:9-13: 2 Kg. 4:29; 1 Sa. 25:5; Nu. 18:31; (5) Lk. 14:25-7//Mt. 10:37,38: Dt. 33:9.

66E.g.: (1) Lk. 6:46/ /Mt. 7:21: Mal. 1:6; (2) Lk. 7:22,23//Mt. 11:4-6: Is. 29:18; 35:5,6; 42:18; 26:19; 61:1; (3) Lk. 13:34,35//Mt. 23:37-9: Is. 31:5; Dt. 32:11; Ps. 91:4; 1 Ki. 9:7; Jr. 12:7; 22:5.

67E.g.: (1) Lk. 7:18-20//Mt. 11:2,3: Ps. 118:26; (2) Lk. 11:21,22//Mt. 12:19: Is. 49:24; 53:12; (3) Lk. 13:34,35//Mt. 23:37-9: Ps. 118:26.

68E.g.: (1) Lk. 6:23//Mt. 5:11: 2 Chr. 36:16; (2) Lk. 11:51//Mt. 23:35,6: Ge. 4:8,10; 2 Chr. 24:20-3: Zech. 1:1.

${ }^{69}$ E.g.: Lk. 7:27//Mt. 11:10: Ex. 23:20; Mal. 3:1.

70E.g.: Lk. 13:28,29//Mt. 8:11,12: Is. 43:5; 49:12; 59:19.

${ }^{71}$ M. Sato, $Q$ und Prophetie, WUNT 2/29, (Tübingen, J.C.B. Mohr 1988) 95: 'Der wichtigste Punkt jedoch, der $Q$ über die Makrogattung "Prophetenbuch" hinausrücken wird, besteht vor allem in der Gestalt des Sprechers Jesus selbst: Jesus in $Q$ nimmt als für das Heil am Eschaton entscheidende Person die göttliche Stellung ein. Daraus stammt auch die einmalige christologische Gliederung der Stellung 
On the other hand, the Old Testament background does provide hints that the $Q$ material may, in fact, complement Mark's portrait of Jesus and the 'orthodox' kerygma which Mark represents. Hints emerge from the multiple quotations and allusions to the book of Isaiah in $\mathrm{Q}$. Two $Q$ pericopes in particular serve notice that Jesus interpreted himself in the light of Isaiah.

\section{Luke 11:21,22//Matthew 12:2972}

Past commentators including K.H. Rengstorf, 73 J.M. Creed, 74 W. Grundmann,75 W. Manson,76 A. Plummer,77 and Barnabas Lindars ${ }^{78}$ have identified this passage as a direct allusion to Isaiah 53:12 - the only verse in the 'Servant Songs' which directly identifies the vicarious suffering and death of the servant. Lindars claims, for example, that in Luke 11:22//Matthew 12:29, 'A saying of Jesus has been given messianic application and linked to the "plot" of Isaiah 53. The Passion is not mentioned, but is assumed in the struggle with the strong man'.79 Recently, however, scholars have been hesitant to make this connection for three primary reasons: (1) the verbal similarities are limited between the $Q$ passage and Isaiah 53:12; (2) there is not a clear conceptual parallel between the two passages; and (3) 'the strong' are the recipients rather than the conquerors in the Hebrew text. For these reasons,

des Propheten ist in den alttestamentlichen Prophetenbüchern nicht geschehen'.

72 Verbatim agreements between the Mt. and Lk. sayings are limited to

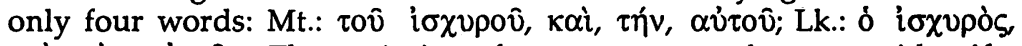
$\kappa \alpha \grave{i}, \tau \dot{\alpha}, \alpha \dot{v} \tau 0 \hat{v}$. The majority of commentators, however, identify this as a $\mathrm{Q}$ passage. See J. Kloppenborg, $Q$ Parallels (Sonoma, Polebridge 1988) 92.

${ }^{73}$ K.H. Rengstorf, Das Evangelium nach Lukas (Göttingen, Vandenhoeck \& Ruprecht 1958) 149.

74J.M. Creed, The Gospel According to St. Luke (London, Macmillan 1930) 161.

${ }^{75}$ W. Grundmann, Das Evangelium nach Lukas (Berlin, Evangelische Verlagsanstalt 1961) 239.

${ }^{76} \mathrm{~T}$.W. Manson, The Gospel of Luke (London, Hodder and Stoughton 1930) 130.

${ }^{77}$ A. Plummer, The Gospel According to St. Luke (Edinburgh, T. \& T. Clark 1901) 303.

78B. Lindars, New Testament Apologetic (London, SCM 1961) 85.

${ }^{79}$ lbid. 
R.T. France, 80 J. Jeremias, 81 I.H. Marshall, 82 and J. Fitzmyer 83 have cited this text as a possible reference to Isaiah 53:12, but have not pressed the connection for Christological conclusions.

We likewise do not want to go beyond the evidence, but we find it sufficient in our present argument to point out that the verbal parallels to Isaiah 53:12, though scant, do exist ${ }^{84}$ (enough for Nestle-Aland (26) to record it as an allusion). Further, the most probable conceptual background for Luke 11:22//Matthew 12:29 is a combination of Isaiah 49:24f. and Isaiah 53:12: in 49:24 it is the mighty man's prey which is taken: 'Can the prey be taken from the mighty man, Or the captives of a tyrant be rescued?' while the verbal parallel to the spoils $\sigma \kappa \hat{v} \lambda \alpha$ (53:12) is closer. Even Morna Hooker, who consistently rejects the association of Jesus with the servant, concedes the conceptual imagery of 49:24 when she writes, 'Although there is no verbal correspondence between the Greek text and the LXX version of Isaiah 49:24f., the similarity in meaning is so great that there is little doubt that Jesus had this passage in mind when he spoke these words;. . .85 We do have, then, at minimum, a $Q$ passage which presents Jesus interpreting his work in the light of Isaiah 53 if not in direct reference to Isaiah 53 itself. This evidence does not prove that Jesus interprets his impending death in the light of Isaiah 53:12 (the death of the servant is not alluded to), but it does suggest that in $Q$ Jesus interprets his work according to an Old Testament passage which appears important to Jesus in Mark 10:45 and elsewhere in the synoptic gospels. Luke 11:21,22//Matthew 12:29, therefore, questions the so-called heretical or variant nature of $Q$.

\section{Luke 7:22,23//Matthew 11:4-6}

Theses verses present Jesus answering John the Baptist's question 'Are you the coming one?' without a simple yes or no. Instead, Jesus tells John's messengers to report back that in Jesus' ministry the blind receive their sight, the lame walk, lepers are cleansed, the deaf hear, the dead are raised up, and

${ }^{80}$ France, $\operatorname{TynB} 19,43$.

81J. Jeremias, TDNT V, 713.

82Marshall, Luke, 477.

${ }^{83}$ Fitzmyer, op. cit., 923.

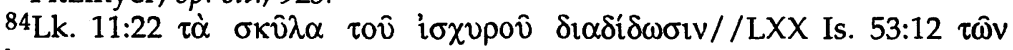
i $\sigma \chi \cup \rho \hat{v} \nu \mu \varepsilon p l \varepsilon \hat{\imath}$ $\sigma \kappa \hat{\lambda} \alpha$.

85 Hooker, op. cit., 74. 
the poor hear good news. Together these acts of Jesus represent the fulfilment of Isaiah 26:19; 29:18f.; 35:5f., and 61:1f.

To be sure, none of these passages represent servant songs or the suffering servant in particular, but close similarities do exist between the figure of Isaiah 61:1-3 and the mission of the servant in Is. 42:1-7.86 Both, for instance, are anointed with the spirit $(42: 11 ; 61: 1)$ and both proclaim freedom to prisoners $(42: 7 ; 61: 1)$. In addition, the restoration of fortunes in 61:1 is reminiscent of the task of the servant in 49:6. It is also important to observe that the first person is used to describe the mission of Isaiah 61:1 and that of the second and third Servant Songs, but nowhere between Isaiah 40 and 66 does the writing prophet use the first person to describe his own work. Such evidence suggests a link between Isaiah 61 and the Servant Songs. There is a hint within $Q$, therefore, that Jesus interpreted his ministry in terms of the suffering servant of Isaiah. Addressing this possibility, R.T. France writes:

Certainly, Jesus can hardly have failed to notice the similarity of these two figures, which stand so close together in the same book of the Old Testament, and the fact that He so emphatically applied the one to His own work must therefore strongly suggest, though it cannot prove, that He would have regarded the other as no less applicable. ${ }^{87}$

To France's comment we may add that it is very unlikely that Jesus would have perceived a contradictory distinction between Isaiah 61 and the Servant Songs so that by applying one passage to his mission he somehow rejected the other. We are left, then, with the important fact which cannot be questioned that Jesus does indeed interpret his mission in $Q$ in

86F.F. Bruce, This is That (Exeter, 1969) 90; C.H. Dodd, According to the Scriptures (London, Nisbet 1952) 94; E. Ellis, Luke (London, Nelson 1966) 97,119,120; Marshall, Luke, 183; Hooker agrees that the two figures were likely to have been joined in Jesus' time: op. cit., 84. M. de Jonge and A.S. van der Woude note that Is. 52:7 and 61:1f. are linked together in the Qumran literature: ' $11 Q$ Melchizedek and the New Testament', NTS 12 (1965-66) 301-26. On the Qumran material see also David Hill, 'The Rejection of Jesus at Nazareth (Luke IV 16-30)', NovT 13 (1971) 161-80; James Sanders, 'From Isaiah 61 to Luke 4', Christianity, Judaism and other Greco-Roman Cults, FS Morton Smith, (ed. J. Neusner) (Leiden, E.J. Brill 1975) 75-106.

87France, op.cit., 43. 
the light of Isaiah $61-$ a passage very close in context to the Servant Songs. Though this fact does not prove our argument that $Q$ complements the passion kerygma of Mark, it does provide confirmatory evidence.

On the other hand, there can be no doubt that in fulfilling the role of the Isaianic herald of Good News, Jesus in the $Q$ material embarks on a ministry characterized by the very same attributes which set Jesus apart in the Galilean ministry of Mark: the anointing of the Spirit, the proclamation of Good News to the poor, and the successful performance of miracles to the blind, lame, deaf, and dumb. In both Mark and $Q$ the burden of Jesus' message is his proclamation that the eschatological saving power of God is present in his own ministry.

\section{Conclusion: The $\mathbf{Q}$ Material is Synoptic Not Heretical}

In conclusion, we have argued that the absence of references to Jesus' death does not constitute evidence that $Q$ contains a heretical kerygma because Q's silence is understandable in the light of similar silence on the part of the Gospel writers themselves; because Jesus is, in fact, a rejected figure in $Q$; and, because there are $Q$ allusions to passages in Isaiah which complement rather than contradict Mark's portrait of Jesus as the suffering Son of Man. Despite these arguments it remains true that $Q$ does not contain an explicit suffering Son of Man saying or a single statement which qualifies the meaning of Jesus' death. Why is this the case if a heretical community is not responsible? We close with four possible reasons. First, it is likely as J. Jeremias suspects, that the limited number of references to Isaiah 53 in the synoptic Gospels reflects the fact that Jesus did not express the Servant role publicly, but only identified himself with the Servant before his disciples.88 Following this argument, we may reason that if $Q$ was addressed to a broad audience as its contents generally suggest, then, we would not expect to find within $Q$ references to the Suffering Servant. Second, despite recent arguments to the contrary, it is probable that the sayings of Jesus were utilized in a teaching or preaching situation in which

88Jeremias, op.cit., 717. 
knowledge of Jesus' death and resurrection were understood. 89 Third, passion allusions are few and interpretative statements of Jesus' death are absent in $Q$ possibly because Jesus did not emphasize his own death until relatively late in his ministry. Matthew, Mark, and Luke agree in locating all of their suffering Son of Man sayings after Peter's confession at Caesarea Phillipi. Is there sufficient reason to doubt the Evangelists' placement of this material?90 If a body of sayings such as $\mathrm{Q}$ was actually recorded early or midway into Jesus' ministry we would hardly expect them to include passion terminology. Fourth, and last, there may be a clue to our puzzle in Jesus' answer to John: 'the blind receive sight, the lame walk, the lepers are cleansed, the deaf hear, the dead are raised, and the poor are evangelized' (Lk. 7:22,23//Mt. 11:4-6). Here Jesus allows his mighty acts rather than an affirmative yes or no to determine his identity. So it may well be with his death and resurrection. On infrequent occasions he openly anticipated his death, but in the end he allowed his actual crucifixion, resurrection, and exaltation to speak for themselves.

Hence evidence supporting a variant kerygma in $Q$ does not stand up to critical evaluation. The $Q$ material does not mesh with $W$. Bauer's paradigm of Christian origins. We have found the content of the $Q$ passages which are said to bear witness to variant thought to be characteristic of the synoptics as a whole. The argument from silence is weak. We, therefore, echo the caveat expressed long ago by Adolf Harnack:

A sceptic acquainted with the comparative history of religions will perhaps find even more here. He will argue as follows: The most

${ }^{89}$ This is the conclusion of T.W. Manson, 'The most probable explanation is that there is no Passion-story because none is required, $Q$ being a book of instruction for people who are already Christians and know the story of the Cross by heart', The Sayings of Jesus (London, SCM 1949) 16. Many scholars follow Manson in this conclusion.

${ }^{90}$ Kloppenborg's scepticism is unwarranted: 'Easter Faith and the Sayings Gospel $Q$ ', 89: 'Our inclination to read $Q$ as a collection of preEaster sayings of Jesus derives from our knowledge of the latter evangelists' placement of $Q$. It may be doubted whether $Q$ intended such a reading'. However, the verisimilitude of the Evangelists' placement of $Q$ is far more believable than Kloppenborg's apparent knowledge of what ' $Q$ intended'. 
ancient source which we possess for the life of Jesus knows nothing of His death upon the cross ... I regard it as quite possible that we shall very soon have to listen to this or to similar absurdities. The beginning is already made. In fact, there are far too many possible explanations of this remarkable limitation of $Q$, and above all, our knowledge of $Q$ and of its conclusion is far too uncertain to allow of the building up a critical theory upon such a foundation. 91

Unfortunately Harnack's fear has been realized in the growing number of critical works on the $Q$ material which presuppose $Q$ to be the literary production of an esoteric community as opposed to the historical Jesus. The $Q$ material is Jewish in background, synoptic in context, and dominical in origin according to the documents in which $Q$ exists. ${ }^{92}$

Therefore, to those who emphasize the silence of $Q$ the alternative question must be raised: if the $Q$ material contains authentic material from the early and middles stages of Jesus' earthly ministry where Matthew and Luke agree in placing it, why should $Q$ contain explicit or even allusive references to Jesus' passion experience? On the other hand, in the postresurrection situation of the early Church, there is every reason to perceive why early followers of Jesus retained and valued the $Q$ material as they sought to identify with and follow their Lord in an atmosphere of persecution.

${ }^{91}$ A. Harnack, The Sayings of Jesus (New York, Putnam's 1908) 233,234 n. 1.

${ }^{92}$ M. Casey, From Jewish Prophet to Gentile God (Cambridge, James Clarke \& Co 1991) 148: 'There is sufficient evidence that some parts of the tradition were written down in Aramaic. These include Marcan narratives, as well as sayings in Q. We must deduce that Aramaicspeaking people handed on these pieces at a time when eye-witnesses were available to tell of their experiences. The access of the evangelists to these traditions explains the large proportion of authentic material in $\mathrm{Mk}$. and $\mathrm{Q}^{\prime}$. 